\title{
Implementation of Backpropagation Artificial Neural Network as a Forecasting System of Power Transformer Peak Load at Bumiayu Substation
}

\author{
Febrian Dhimas Syahfitra ${ }^{1}$, Ramadoni Syahputra ${ }^{* 2}$, Karisma Trinanda Putra ${ }^{3}$ \\ ${ }^{1,2,3}$ Department of Electrical Engineering, Universitas Muhammadiyah Yogyakarta \\ Jl. Lingkar Barat, Tamantirto, Kasihan, Bantul, (0274) 387656 \\ *Corresponding author, e-mail: ramadoni@umy.ac.id
}

\begin{abstract}
The National Electricity Company (PT PLN) should have an estimated peak load of the substation transformer in the future. This is useful to be able to achieve transformer capability and can be used as a first step to anticipate the possibility of replacement of a new transformer. This research presents a peak load forecasting system transformerl and transformer 2 in Bumiayu substation using Backpropagation Artificial Neural Network (ANN). This study includes the procedures for establishing a network model and manufacture forecasting system based GUI (Graphic User Interface) using MATLAB 2015a. The formation of the network model refers to input variables consisting of GRDP data, population data and historical data of peak load of transformer. In this research, a multilayer network model, which consists of 1 input layer, 2 hidden layers and 1 output layer, is used. The peak load forecasting of transformerl produces 5.7593e-08 for training MSE and 5.3784e-04 for testing MSE. Meanwhile, forecasting the peak load transformer2 generated 3.3433e-08 for training MSE and 9,4710e-04 for testing MSE. Copyright (C) 2017 Universitas Muhammadiyah Yogyakarta-All rights reserved.
\end{abstract}

Keywords: peak load forecasting, Artificial Neural Network (ANN), Backpropagation, MATLAB

\section{Introduction}

The more the population and the growth of economic side should be directly proportional to the energy available in Indonesia [1-7]. The availability of sufficient electrical energy can affect the quality of life, because of the functional side of this electrical energy is to support industry or business entities, public utilities and even households [8-10]. If the energy supply is not sufficient to meet the needs, it will impede economic growth [11]. In addition, the level of community satisfaction in terms of electrical energy services will be reduced [12-18].

The substation is a part of a power system which has main component that is power transformer. Transformer serves to transform electrical power by changing the system voltage [19-23]. The capacity of substation power transformer needs to be considered, it is intended to be aware of the range of power transformer's ability to meet the needs of consumer electricity. If the load borne by the power transformer increases, the longer the load will exceed the capacity of the transformer. This will cause the transformer overload, and will decrease the quality of electric energy services to customers [24]. Therefore, PLN must have an estimated peak load of the transformer in the future. This is useful for reaching the ability of the transformer in the next few years and also PLN can perform early anticipation for the possible replacement of a new transformer. This is achieved by means of forecasting [25-29].

One method of forecasting is artificial neural network (ANN). ANN is a system based on the workings of human neural networks [25]. One type of ANN is backpropagation, this type is chosen because when output is not the same as the expected target then the output will be backward on the hidden layer to be passed to the input layer, so there will be feedback to validate the output of ANN. 


\section{Forecasting of Power Transformer Peak Load}

Forecasting is a process to estimate events / things in the future. Forecasting requires historical data and projects it into the future with some mathematical models [4]. Transformer peak load forecasting can be categorized as quantitative forecasting. This quantitative forecasting can be applied if the following 3 conditions are met:

- There is information about the past

- Such information can be quantified in the form of numerical data

- It can be assumed that some aspects of past patterns will continue in the future

\subsection{Backpropagation Algorithm}

Backpropagation is a supervised learning algorithm and is typically used by a perceptron with many layers to change the weights connected to existing neurons in the hidden layer. Backpropagation algorithm using output error to change the value of the weights is backward. To get this error, forward propagation stage must be done first.

There are 3 (three) standard backpropagation algorithm that is backpropagation architecture, activation function and standard training. [12]

1. Backpropagation architecture

Backpropagation has several units that exist in one or more hidden layers. Figure 1 is a backpropagation architecture with $\mathrm{n}$ inputs (plus one bias), a hidden layer consisting of $p$ units (plus a bias), as well as m units

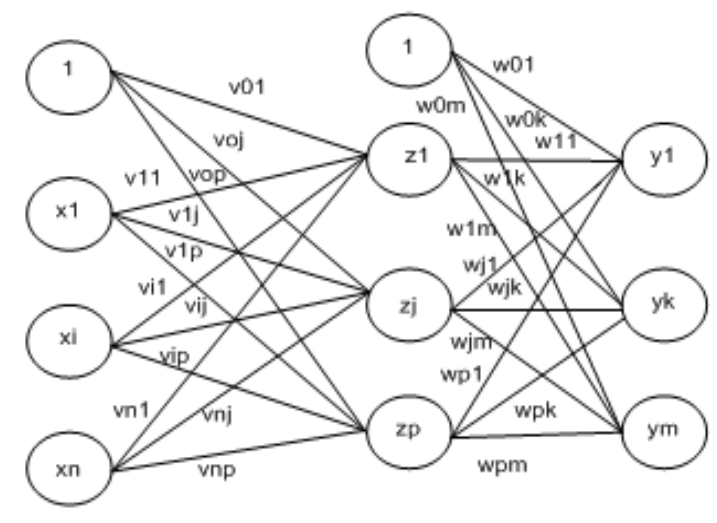

Fig. 1 Backpropagation architecture

\section{Activation function}

In backpropagation, the activation function used must meet several conditions, namely: continuous, differentiated easily and is a function that does not go down. One function that meets these three requirements so often used is a binary sigmoid function that has a range $(0$, 1). Another function that is often used is a bipolar sigmoid function whose form and function is similar to the binary sigmoid function, but with the range $(-1,1)$

\section{Standard training}

Backpropagation training includes 3 phases. The first phase is the forward phase. In this phase, input patterns are calculated forward from the input screen to the output screen using the activation function defined. The second phase is the backward phase. The difference between the output of the network and the desired target is an error occurring. The error is propagated backwards, starting from a line directly related to the units on the output screen. The third phase is the modification of weight to reduce errors that occur.

\subsection{Transformer}

The transformer is a device used to transform electrical power by raising or lowering the voltage, but with a fixed frequency on the primary and secondary sides. [14]

The transformer loading or transformer load factor is obtained through the division between the peak load forecast and the transformer capacity. The value of the transformer capacity can be seen in the data sheet.

TABLE I

TRANSFORMER LOAD FACTOR CATEGORIES

\begin{tabular}{cc}
\hline \hline Rating values & Information \\
\hline$<60 \%$ & light load \\
$60 \%-80 \%$ & optimum load \\
$80 \%-100 \%$ & heavy load \\
$>100 \%$ & overload \\
\hline \hline
\end{tabular}

\section{Research Methodology}

In this research there are several steps work done to achieve the desired end result

\subsection{Identification and Problem Formulation}

In identifying the problem, it is necessary to observe directly on the object of research and conduct interviews with the authorities in the field. It is intended that the problem to be analyzed has the depth of material and information 


\subsection{Literature Study}

Literature study is conducted to deepen the subject of discussion and as a basis for reviewing certain factors in conducting research analysis. The material obtained can be derived from reference books, internet, and related literature. The theories studied are:

- Theory about substations.

- Theory of artificial neural networks

- The theory of forecasting / projection of transformer loads.

\subsection{Data Collection}

The data collected from the Bumiayu Substation are the historical data of the transformer peak load installed in the Bumiayu Substation for several years back and also the data sheet of the transformer specification. In addition, data was also obtained from the Central Statistics Agency (BPS) Brebes on population data and GDP Brebes Regency.

\subsection{Data Processing}

Data is processed by sorting and grouping by category, according to research needs. After the grouping, then the data is then processed based on the need to be used as input network. The input data consists of training data and target data.

\subsection{Design, Manufacture and System Application}

The design consists of several parts, namely system design, network architecture, training, testing and implementation of forecasting.

From the design results, then made a GUIbased system. Creation of GUI-based system for forecasting peak load of this transformer using MATLAB software 2015a. Once the system is successfully established, then the application of forecasting uses the system has been built

\subsection{Data Analysis}

Conducted data analysis on the training process and testing process. This training process produces network weights and can be seen matching the targets with the network output. From the training results, then tested whether the network has been built as expected. If there is a match between the target and the network output, then it can be concluded that the network has been built can be applied for forecasting.

\subsection{Improving the Manuscript}

The result of data analysis from the transformer forecasting model has been made, then compiled as a final report. In the writing of the final task must be in accordance with the standard rules.

\section{Research Result}

4.1 Establishment of Network Model.

1. Input Data

TABLE 2

DATA ON TRANSFORMATOR1 NETWORK

\begin{tabular}{|c|c|c|c|c|c|}
\hline \multicolumn{6}{|c|}{ Training } \\
\hline No & 1 & 2 & 3 & 4 & 5 \\
\hline X1 & 2,162 & 2,457 & 2,646 & 2,943 & 3,315 \\
\hline $\mathrm{X} 2$ & 2,457 & 2,646 & 2,943 & 3,315 & 3,695 \\
\hline X3 & 1,859 & 1,869 & 1,878 & 1,893 & 1,903 \\
\hline X4 & 1,869 & 1,878 & 1,893 & 1,903 & 1,909 \\
\hline X5 & 8,8 & 11,3 & 10,1 & 11,1 & 13,3 \\
\hline Target & 11,3 & 10,1 & 11,1 & 13,3 & 28,9 \\
\hline \multicolumn{6}{|c|}{ Testing } \\
\hline & No & & 1 & 2 & 3 \\
\hline & X1 & & 2,943 & 3,315 & 3,695 \\
\hline & $\mathrm{X} 2$ & & 3,315 & 3,695 & 4,005 \\
\hline & $\mathbf{X} 3$ & & 1,893 & 1,903 & 1,909 \\
\hline & X4 & & 1,903 & 1,909 & 1,916 \\
\hline & X5 & & 11,1 & 13,3 & 28,9 \\
\hline & Target & & 13,3 & 28,9 & 27,1 \\
\hline
\end{tabular}

TABLE 3

DATA ON TRANSFORMATOR2 NETWORK

\begin{tabular}{cccccc}
\hline \hline \multicolumn{7}{c}{ Training } \\
\hline No & $\mathbf{1}$ & $\mathbf{2}$ & $\mathbf{3}$ & $\mathbf{4}$ & $\mathbf{5}$ \\
\hline $\mathbf{X 1}$ & 3,32 & 3,67 & 3,953 & 4,396 & 4,951 \\
$\mathbf{X 2}$ & 3,67 & 3,953 & 4,396 & 4,951 & 5,52 \\
$\mathbf{X 3}$ & 2,782 & 2,792 & 2,806 & 2,833 & 2,848 \\
$\mathbf{X 4}$ & 2,792 & 2,806 & 2,833 & 2,848 & 2,849 \\
$\mathbf{X 5}$ & 23,5 & 33,1 & 17,9 & 19,4 & 23,5 \\
Target & 33,1 & 17,9 & 19,4 & 23,5 & 22,1 \\
\hline \multicolumn{7}{c}{ Testing } \\
\hline \hline \multicolumn{7}{c}{$\mathbf{1}$} \\
\hline \multicolumn{7}{c}{ No } & 4,396 & 4,951 & 5,52 \\
& X1 & 4,951 & 5,52 & 5,983 \\
& X2 & \multicolumn{2}{c}{$\mathbf{2}$} \\
& X3 & & 2,833 & 2,848 & 2,849 \\
& X4 & & 2,848 & 2,849 & 2,86 \\
& X5 & & 19,4 & 23,5 & 22,1 \\
& Target & 23,5 & 22,1 & 22,4 \\
\hline
\end{tabular}


Network input variables consist of:

- X1 = GRDP (T-2)

$-\mathrm{X} 2=$ GRDP $(\mathrm{T}-1)$

- X3 = Population (T-2)

- X4 = Population $(\mathrm{T}-1)$

$-\mathrm{X} 5$ = Peak load (T-1)

The data on transformator1 network and transformer2 network has been shown in Table 2.

\section{Network Model}

The network formed in this study is a multilayer network consisting of 1 input layer, 2 hidden layers and 1 output layer. The number of neurons in each hidden layer is 30 neurons in the first hidden layer and 10 neurons in the second hidden layer.

\subsection{Creation of GUI Based Forecasting System}

The GUI system for both transformer forecasting systems consists of 3 pages (figures) ie Home, Simulation and Implementation. All three pages are connected and integrated with each other. However, in applying neural network model in this research, source code to build artificial neural network is made separately from GUI that is in the form of function. This function runs when called through the callback () command by the GUI in question.

\section{Home page}

Home page is the first page opened by user. It can be seen in the picture above that the Home page for the peak load prediction of transformer1 is the same as the Home page for the peak load prediction of transformer2

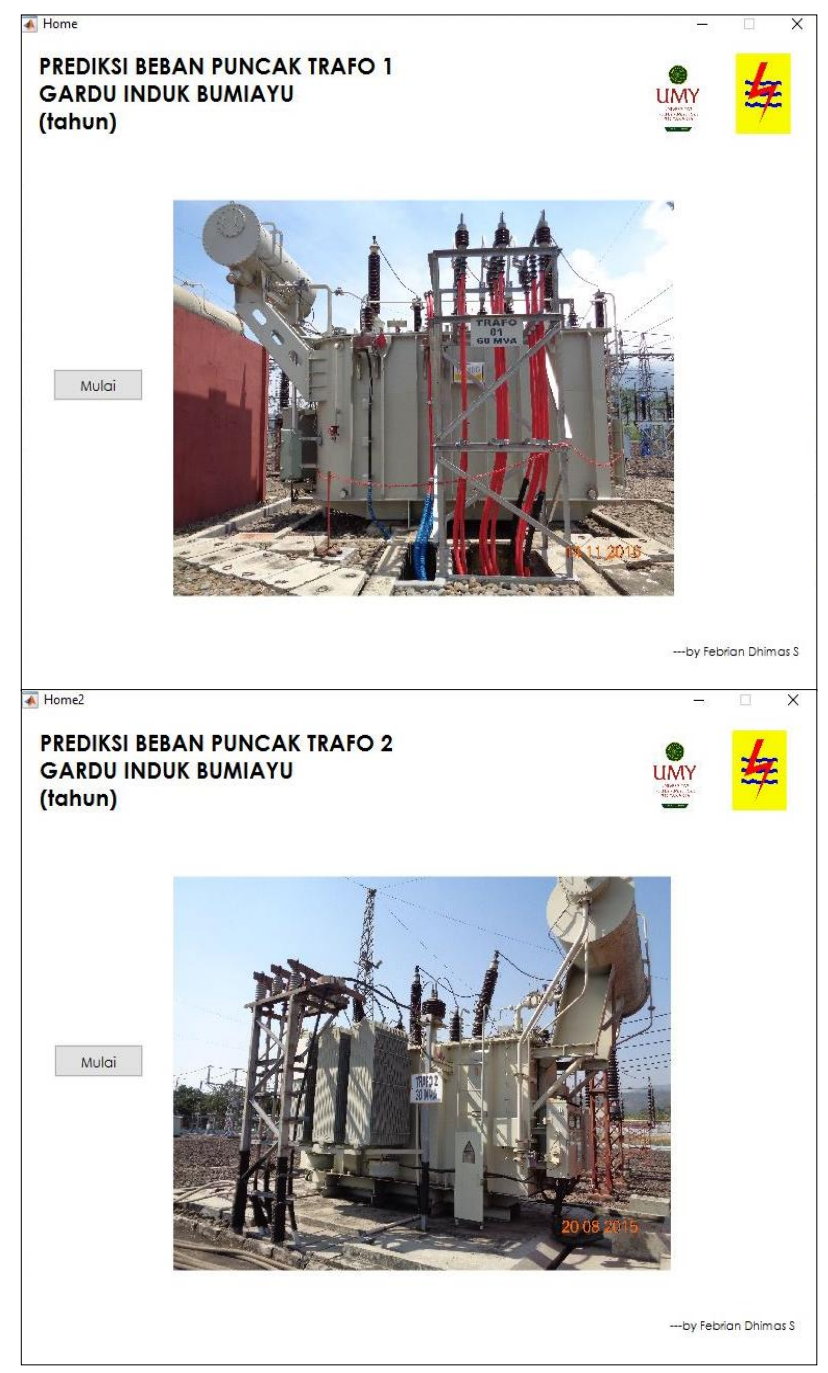

Fig. 2 Home page Transformer1 \& Transformator2

\section{Simulation page}

Simulation page is a page for establishing a network consisting of a training process and also a testing process. On the Simulation page, the user can set or input parameter values that may affect network training. 


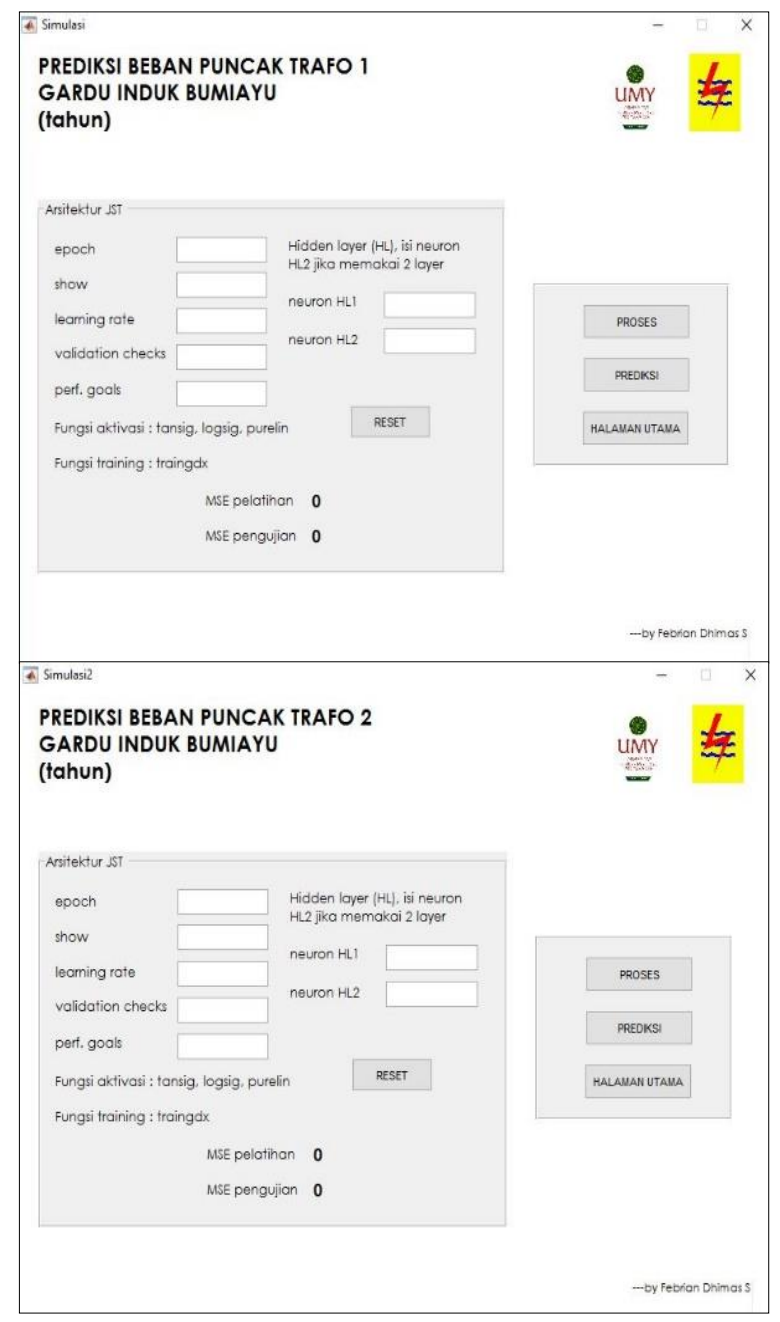

Fig. 3 Simulation page of Transformer1 \& Transformator2

a.Network Transformer 1

In this section, network training and network testing is described.

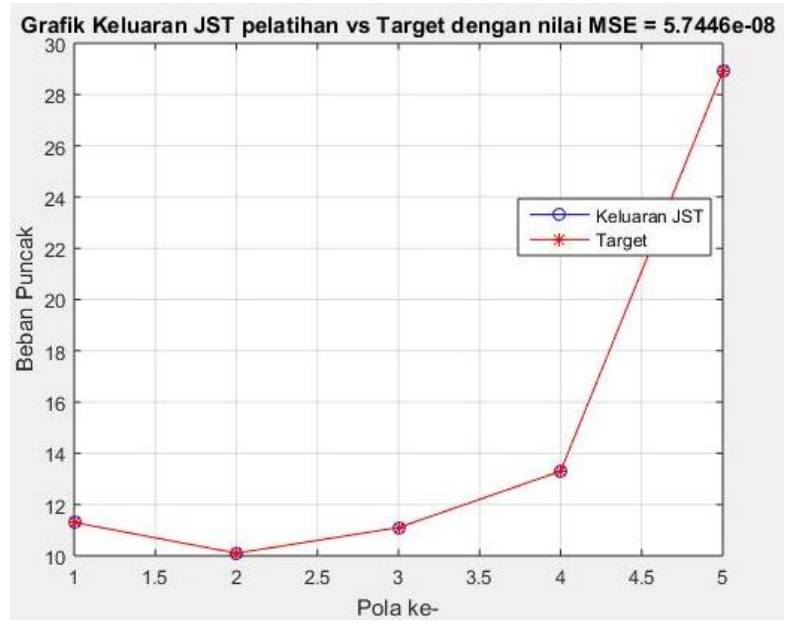

Fig. 4 Network training results Transformator1
From Figure 4 it is found that the target value to the network training output has a similarity value. MSE1 (MSE training) generated by transformer1 network is 5,7446e-08. This result is achieved by iterating as many as 113 iterations.

Furthermore, after the training, the network needs to be tested to determine whether the relevant network is formed or not. the largest difference between the network testing output and the target is 0.04 .

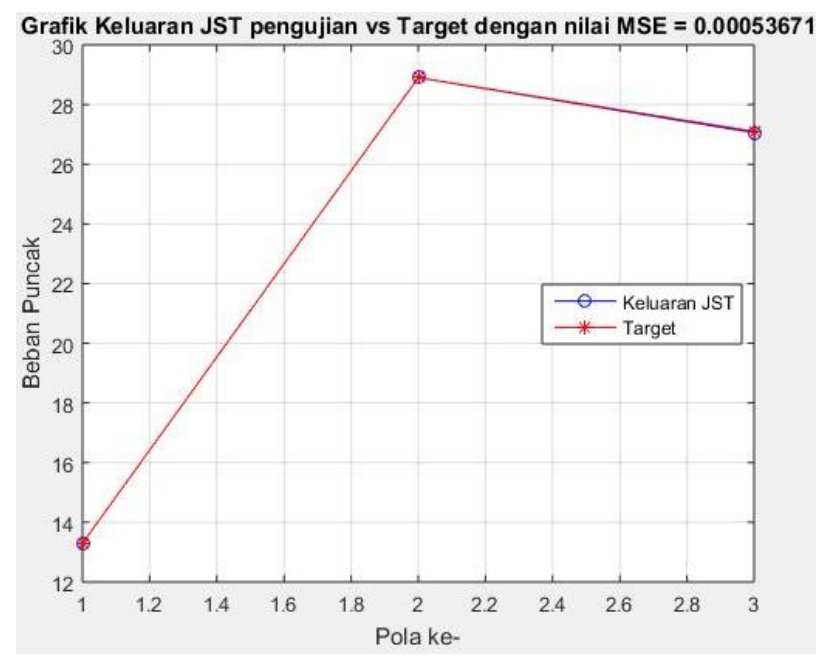

Fig. 5 Network testing results Transformator 1

b. Network Transformer2

In this section, network training and network testing is described.

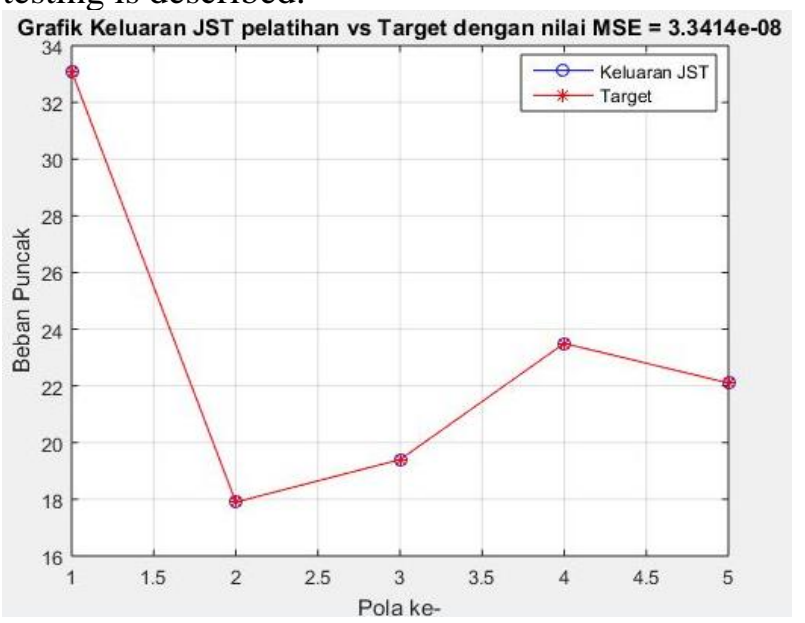

Fig. 6 Network training results Transformator2

Based on Figure 6, it can be seen that the target value with the network training output has the difference in each input pattern almost reaching the number 0 . The value of MSE1 (MSE training) produced is $3,3414 \mathrm{e}-08$. The result is achieved with 67 iterations. 
The transformer2 network testing resulted in MSE testing of 9.3161e-04, with the largest difference between the network test output and the target being 0.05 .

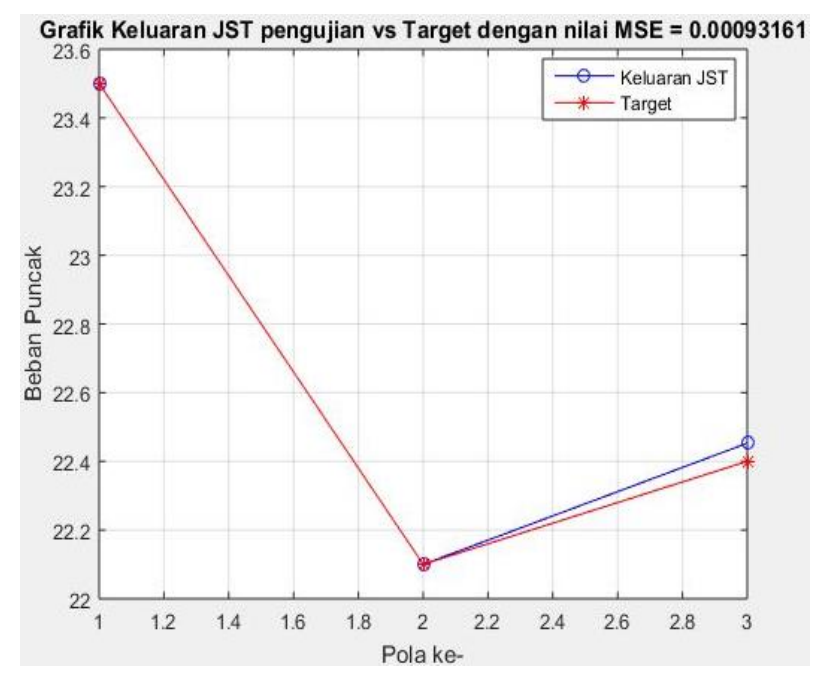

Fig. 7 Network testing results Transformator2

\section{Implementation page}

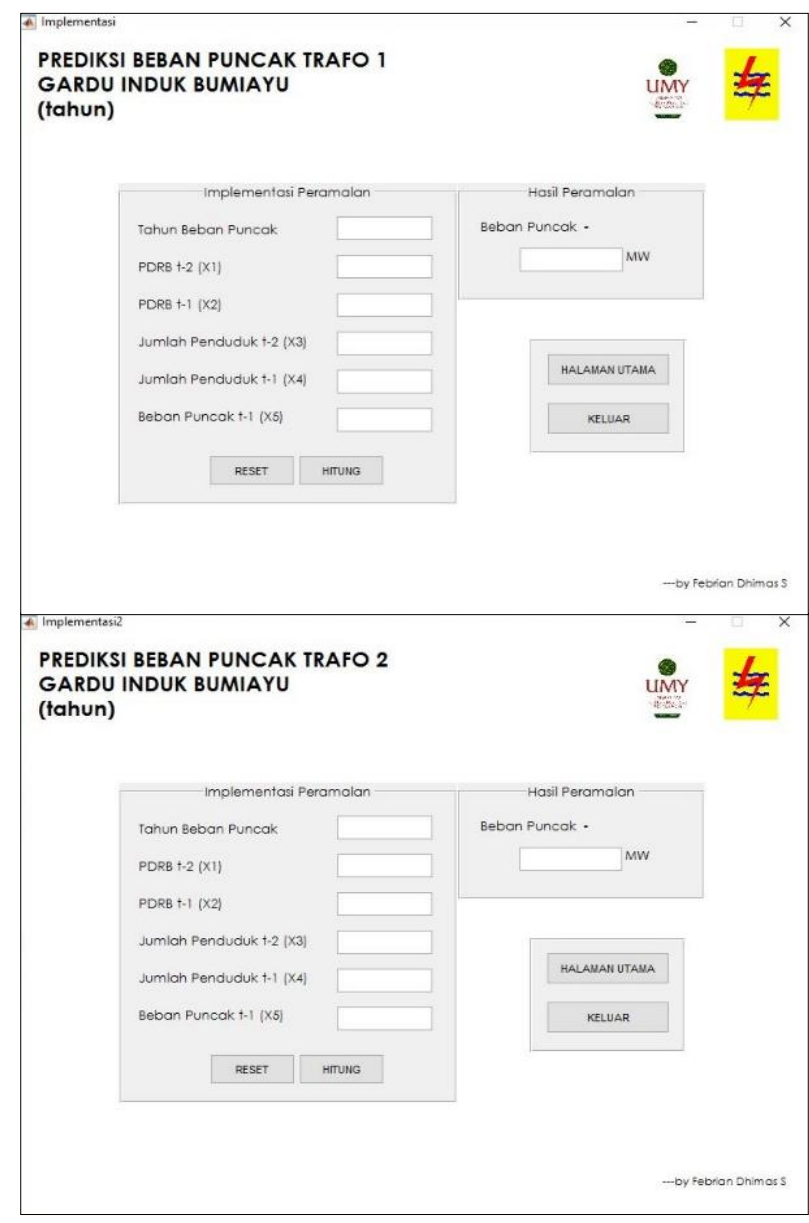

Fig. 8 Implementation page of Transformer1 \& Transformator2
Implementation page is a page to forecast the transformer peak load based on the network model that has been formed. On the Implementation page, user can enter the values of variables (X1, X2, X3, $\mathrm{X} 4, \mathrm{X} 5)$ as inputs for the peak load prediction of transformer.

4.3 Implementation of transformer peak load forecasting

The forecast input consisting of $\mathrm{X} 1, \mathrm{X} 2, \mathrm{X} 3$, $\mathrm{X} 4$ and $\mathrm{X} 5$ is manually entered by the user into the textbox edit component on the Implementation page. Unlike the others, X5 value obtained gradually each year. This is because X5 is the peak load data of the transformer in the previous year.

\section{Forecasting peak load of transformer1}

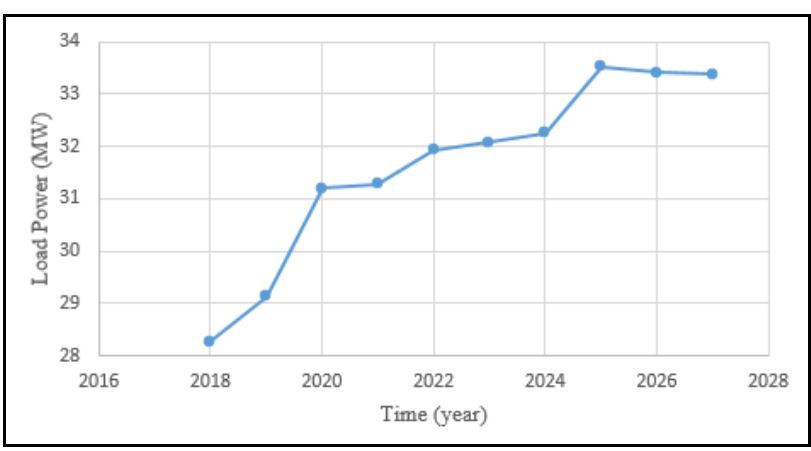

Fig. 9 The chart of forecasting peak load transformer1

It can be seen in Table 4 and Figure 9 which shows that the results predicted peak load transformator1 have an upward trend each year. This is directly proportional to the increase in GRDP value and the number of population served by transformer1. In 2027, the predicted peak load of the transformer is $33.39 \mathrm{MW}$. That number reaches $55.65 \%$ of transformer1 capacity, and can be categorized as an light standard of transformer load.

\section{Forecasting peak load of transformer2}

It can be seen in Table 5 and Figure 10 that the peak load of transformer2 has decreased in 2019 and 2020. However, starting from 2021 onwards, the peak load transformator2 have an upward trend each year. This is directly proportional to the increase in GRDP value and the number of population served by transformer2. In 2027, the predicted peak load of the transformer is 23.17 MW. That number reaches $77.23 \%$ of transformer2 
capacity, and can be categorized as an optimal standard of transformer load.

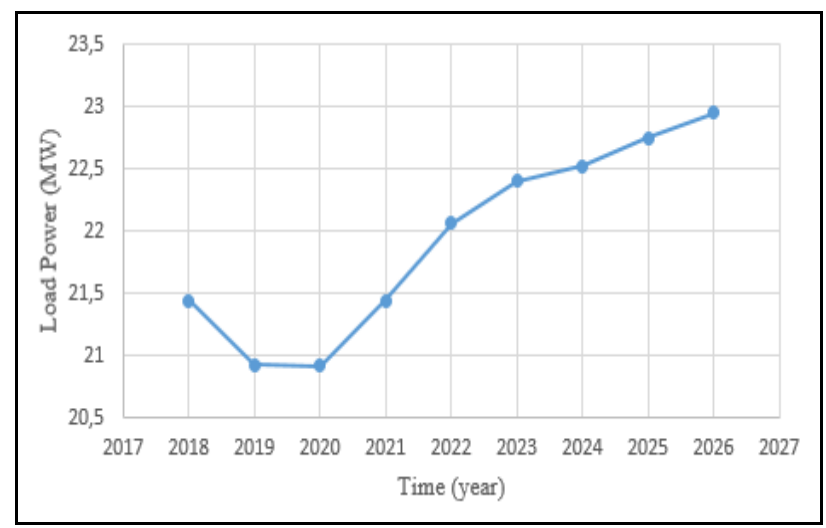

Fig. 10 The chart of forecasting peak load transformer2

\section{Conclusion}

Based on the discussion of the Backpropagation Artificial Neural Network (ANN) algorithm applied to forecasting the power transformer peak load in Bumiayu Substation, it can be concluded as follows.

1. Forecasting the peak load transformer1 generates MSE training of 5.7446e-08 and MSE testing of 5.3671e-04. These results show that the network model built is good enough to be applied to forecasting the peak load of the transformer1. Predicted results from 2018 to 2027 show an upward trend in peak load every year. . In 2027, the predicted peak load of the transformer is $33.39 \mathrm{MW}$. That number reaches $55.65 \%$ of transformer 1 capacity, and can be categorized as an light standard of transformer load.

2. Forecasting the peak load transformer2 generates MSE training of 3.3414e-08 and 9,3161e-04 for MSE testing. From these results indicate that the network model that has been built is good enough to be applied to forecasting the peak load of the transformer2. Predicted results from 2018 to 2027 indicate an upward trend in peak load every year, despite a decline in peak load values in 2019 and 2020. In 2027, the predicted peak load of the transformer is $23.17 \mathrm{MW}$. That number reaches $77.23 \%$ of transformer 2 capacity, and can be categorized as an optimal standard of transformer load.

\section{References}

[1] Fitriyah, Q., Istardi, D. 2011. "Prediksi Beban Listrik Pulau Bali dengan Menggunakan Metode Backpropagasi”. Seminar Nasional Informatika 2011 (semnasIF 2011). UPN Veteran Yogyakarta, 2 July 2011

[2] Fitzgerald, A.E. (1992). "Mesin-Mesin Listrik Edisi Keempat". Jakarta : Penerbit Erlangga.

[3] Haidaroh, A. 2013. "Pengenalan Kecerdasan Buatan (Artificial Intellegence)". Kupang : STIKOM Artha Buana.

[4] Heizer, J., Render, B. (2009). "Manajemen Operasi. Edisi 9. Terjemahan Chriswan Sungkono". Jakarta : Salemba Empat

[5] Kusumadewi, F. (2014). "Peramalan Harga Emas Menggunakan Feedforward Neural Network Dengan Algoritma Backpropagation”. Yogyakarta : Universitas Negeri Yogyakarta.

[6] Laughton, M.A., Warne, D. F.. (2003). "Electrical Engineer's Reference Book 16th Edition". Great Britain : Newnes

[7] Muis, S. (2017). "Jaringan Syaraf Tiruan ; Sistem Kecerdasan Tiruan dengan Kemampuan Belajar dan Adaptasi”. Yogyakarta : Teknosain.

[8] Nurkholiq, N. 2014. "Analisis Perbandingan Metode Logika Fuzzy dengan Jaringan Syaraf Tiruan Backpropagation Pada Peramalan Kebutuhan Energi Listrik Jangka Panjang di Indonesia Sampai Tahun 2022". TRANSIENT Vol. 3, No. 2, ISSN : 2302-9927 (Juni 2014), pp. 245 -251.

[9] Pratama, R. A. Anifah, L. (2016). "Peramalan Beban Listrik Jangka Panjang D.I.Yogyakarta Menggunakan Neural Network Backpropagation”. Jurnal Teknik Elektro. Volume 05 Nomor 03 Tahun 2016, p.p 37-47.

[10] Purnomo, H. (2004). "Peramalan Beban Listrik Jangka Pendek dengan Menggunakan Model Jaringan Syaraf Tiruan di PT. PLN Region III Jawa Tengah dan DIY”. Yogyakarta : Universitas Gadjah Mada.

[11] Purnomo, M.H., Kurniawan, A. (2006). "Supervised Neural Networks dan Aplikasinya". Yogyakarta : Graha Ilmu.

[12] Siang, J. J. (2009). "Jaringan Syaraf Tiruan dan Pemrogramannya Menggunakan MATLAB”. Yogyakarta : ANDI.

[13] Syahputra, R., Soesanti, I. (2016). "Power System Stabilizer Model Using Artificial Immune System for Power System Controlling". International Journal of Applied Engineering Research (IJAER), 11(18), pp. 9269-9278.

[14] Syahputra, R. (2016). "Transmisi dan Distribusi Tenaga Listrik”. Yogyakarta : LP3M UMY Yogyakarta.

[15] Syeto, G. J. (2010). "Peramalan Beban Listrik Menggunakan Jaringan Syaraf Tiruan Metode Kohonen". Surabaya : Institut Teknologi Surabaya. 
[16] Tamizharasi, G dkk. 2014. "Energy Forecasting using Artificial Neural Networks”. IJAREEIE Vol. 3, Issue 3. March 2014, pp. 7568-7576.

[17] Syahputra, R., Soesanti, I., Ashari, M. (2016). Performance Enhancement of Distribution Network with DG Integration Using Modified PSO Algorithm. Journal of Electrical Systems (JES), 12(1), pp. 1-19.

[18] Syahputra, R., Robandi, I., Ashari, M. (2015). Performance Improvement of Radial Distribution Network with Distributed Generation Integration Using Extended Particle Swarm Optimization Algorithm. International Review of Electrical Engineering (IREE), 10(2). pp. 293-304.

[19] Syahputra, R., Robandi, I., Ashari, M. (2014). Optimization of Distribution Network Configuration with Integration of Distributed Energy Resources Using Extended Fuzzy Multi-objective Method. International Review of Electrical Engineering (IREE), 9(3), pp. 629-639.

[20] Syahputra, R., Robandi, I., Ashari, M. (2015). Reconfiguration of Distribution Network with DER Integration Using PSO Algorithm. TELKOMNIKA, 13(3). pp. 759-766.

[21] Syahputra, R., Soesanti, I. (2016). Design of Automatic Electric Batik Stove for Batik Industry. Journal of Theoretical and Applied Information Technology (JATIT), 87(1), pp. 167-175.

[22] Soesanti, I., Syahputra, R. (2016). Batik Production Process Optimization Using Particle Swarm Optimization Method. Journal of Theoretical and Applied Information Technology (JATIT), 86(2), pp. 272-278.

[23] Syahputra, R., Robandi, I., Ashari, M. (2015). PSO Based Multi-objective Optimization for Reconfiguration of Radial Distribution Network. International Journal of Applied Engineering Research (IJAER), 10(6), pp. 14573-14586.

[24] Syahputra, R., Soesanti, I. (2016). DFIG Control Scheme of Wind Power Using ANFIS Method in Electrical Power Grid System. International Journal of Applied Engineering Research (IJAER), 11(7), pp. 5256-5262.

[25] Jamal, A., Suripto, S., Syahputra, R. (2015). MultiBand Power System Stabilizer Model for Power Flow Optimization in Order to Improve Power System Stability. Journal of Theoretical and Applied Information Technology (JATIT), 80(1), pp. 116123.

[26] Syahputra, R., Soesanti, I. (2015). Power System Stabilizer model based on Fuzzy-PSO for improving power system stability. 2015 International Conference on Advanced Mechatronics, Intelligent Manufacture, and Industrial Automation (ICAMIMIA), Surabaya, 15-17 Oct. 2015 pp. 121 126.

[27] Syahputra, R. (2017). Distribution Network Optimization Based on Genetic Algorithm. Jurnal
Teknologi, Journal of Electrical Technology UMY (JET-UMY), 1(1), pp. 1-9.

[28] Syahputra, R., Soesanti, I. (2016). Application of Green Energy for Batik Production Process. Journal of Theoretical and Applied Information Technology (JATIT), 91(2), pp. 249-256.

[29] Syahputra, R. (2016). Application of Neuro-Fuzzy Method for Prediction of Vehicle Fuel Consumption. Journal of Theoretical and Applied Information Technology (JATIT), 86(1), pp. 138-149.

\section{Authors' information}

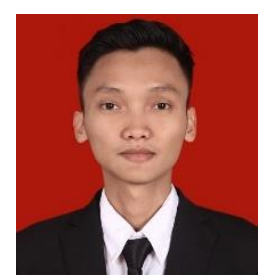

Febrian Dhimas Syahfitra Received B.Sc degree from Department of Electrical Engineering Universitas Muhammadiyah Yogyakarta, Yogyakarta, Indonesia in 2018. His research interests are in computational of power system and artificial neural network in power system.

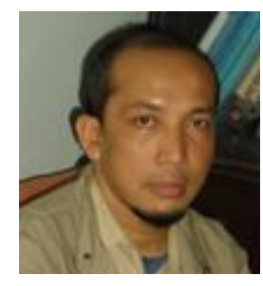

Ramadoni Syahputra received B.Sc. degree from Institut Teknologi Medan in 1998, M.Eng. degree from Department of Electrical Engineering, Universitas Gadjah Mada, Yogyakarta, Indonesia in 2002, and Ph.D degree at the Department of Electrical Engineering, Faculty of Industrial Technology, Institut Teknologi Sepuluh Nopember, Surabaya, Indonesia in 2015.

Dr. Ramadoni Syahputra is a Lecturer in Department of Electrical Engineering, Faculty of Engineering, Universitas Muhammadiyah Yogyakarta, Indonesia. His research interests are in computational of power system, artificial intelligence in power system, power system control, the application of fuzzy logic in power system, optimization, distributed energy resources, and renewable energy.

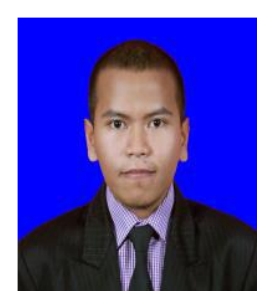

Karisma Trinanda Putra received B.Sc. degree from Department of Electrical Engineering, Politektik Elektronika Negeri Surabaya in 2012, M.T. degree from Department of Electrical Engineering, Faculty of Industrial Technology, Institut Teknologi Sepuluh Nopember, Surabaya, Indonesia in 2015. Karisma Trinanda Putra, M.T. is a Lecturer in Department of Electrical Engineering, Faculty of Engineering, Universitas Muhammadiyah Yogyakarta, Indonesia. His research interests are in intellegent systems and controls. 